\begin{tabular}{ll}
\hline 総 & 説 \\
\hline
\end{tabular}

\title{
蚊の疾病媒介生態に関する野外研究： 特に都市域における最近の研究
}

\author{
津田良夫
}

国立感染症研究所昆虫医科学部（₹ 162-8640 東京都新宿区戸山 1-23-1）

（受領：2011 年 10 月 12 日; 登載決定 2011 年 10 月 27 日）

\begin{abstract}
Recent field studies on vector ecology of mosquitoes in urban areas of Tokyo, Japan Yoshio TsudA

Department of Medical Entomology, National Institute of Infectious Diseases, Toyama 1-23-1, Shinjuku-ku, Tokyo, 162-8640 Japan (E-mail: tsudayso@nih.go.jp)
\end{abstract}

(Received: 12 October 2011; Accepted: 27 October 2011)

\begin{abstract}
Results of two mosquito studies recently conducted in a park in urban Tokyo were introduced and related studies were reviewed. A large number of adult Culex tritaeniorhynchus suddenly appeared from late September to November 2007 during the course of systematic sweep net collections of vegetation in the park. The pre-diapause migration has been observed every year from 2007 to 2010. The time course of pre-diapause migration was similar starting in mid-/late September, peaking in mid-October and ending in December. The density of migrated females and parity differed year by year, and dissection showed that a large part of the females ( 85 to 97\%) were in reproductive diapause. Blood-meal identifications of $C x$. pipiens pallens together with avian malaria parasite detection were conducted by using blood-fed females collected in the study park from May 2007 to May 2008. Thirteen wild bird species were identified as the blood-source and 5 of them were infected with avian malaria parasite. Ten Plasmodium lineages were identified and the three commonest lineages were detected in both the abdomens and thoraxes of mosquitoes, suggested transmission of these lineages. Jungle crow and tree sparrow served as a natural host for the three commonest lineages.
\end{abstract}

Key words: pre-diapause migration, Culex tritaeniorhynchus, Culex pipiens pallens, bloodmeal identification, Plasmodium parasite, transmission of avian malaria parasite

\footnotetext{
緒言

蚊によって媒介される病原体（蚊媒介性病原体）の流 行は, 病原体の媒介能力を有する蚊（媒介蚊）が生息し ていなければ起こらないし, 媒介蚊が生息している地域 であっても病原体が持ち込まれない限り起こらない. 代 表的な蚊媒介性疾患であるマラリアの流行に関する理論
}

的研究では，ある集団でマラリアに感染する人の割合 は時間経過にともなってある值に収束しそのレベルは マラリア媒介蚊の密度に比例して高くなること，また マラリア原虫が持ち込まれたとしても媒介蚊の生息密 度がある臨界密度に達していなければ，新たにマラリ ア原虫に感染する人の数は時間と共に減少し，ついに はマラリア原虫は自然消滅してしまうことが示されて 
いる (Macdonald, 1957; Bailey, 1982; Anderson and May, 1992).このように蚊媒介性病原体の流行は媒介蚊の生 息密度と密接に関係していると考えられるため, 媒介蚊 の生息地域に病原体が持ち込まれていない状況下であっ ても，何らかの病原体が持ち込まれた場合を想定して， どこで, どの程度の流行が起こるかを媒介蚊の生息状況 調査に基づいてある程度予測すること（蚊媒介性感染症 のリスク評価）ができる.マラリアや日本脳炎, デング 熱などの媒介蚊に関する生態的研究は, 基本的にはこの ような理解に基づいて行われてきたということができ る.

蚊媒介性感染症のリスクを評価する上で重要な媒介蚁 集団の情報としては, 地理的分布, 生息密度, 野外での 生存率, 成虫の空間分布, 吸血行動, ヒトとの接触頻 度, 吸血嗜好性, 病原体に対する感受性などが挙げら れる (Kilpatrick et al., 2005; 津田ら, 2005; Kent et al., 2009).これらの情報を収集するために, 野外個体群を 対象とした種々のトラップによる定量採集, 動物囮を用 いた成虫採集, 成虫の記号放逐・再捕獲法など様々な生 態調査法が考案されてきた (Silver, 2008). 近年, 分子生 物学的手法に基づいた蚊からの病原体の検出や吸血蚊を 用いた吸血源動物の同定法が開発され, 従来の生態調査 にこれらの情報を加味することによって, 蚊と蚊によって 媒介される病原体の分子生態学的な研究が可能になった。

現在, 我が国で蚊によって媒介されている人の感染症 は日本脳炎だけであり, 患者数も少ない.したがって, 国内における疾病媒介蚊の野外調査の主な目的は, 媒介 蚊の対策ではなく, 媒介蚊の発生状況を把握し, それに 基づいた蚊媒介性感染症のリスク評価を行うことに置か れている. 従来のライトトラップの代わりにドライアイ スやイースト発酵によって発生させた $\mathrm{CO}_{2}$ を誘引源と する $\mathrm{CO}_{2}$ トラップ(Saitoh et al., 2004)を用いることで, 生態的条件の異なるいろいろな場所で成虫採集を行うこ とが可能になった。 そこで, ある地域にどんな種類の蚊 がどの程度の密度で生息しているのかを明らかにするた めに, $\mathrm{CO}_{2}$ トラップを用いた調查を行ってきた（Higa et al., 2006; 津田ら 2006a, b; Tsuda et al., 2009a, b). また, これらの調査と並行して, 都市域における蚊媒介性感染 症のリスク評価の基礎データとするために, 東京都内の 大規模公園を対象とした蚊の生態調査を行ってきた。こ の都市域の公園を対象として行ってきた疾病媒介蚊の生 態研究の中から $2 つ 0$ 話題を選び, 最新の研究結果につ いて研究の背景を加えて以下に紹介する.

\section{(1) 東京都の公園における蚊の生態研究とコガタアカイ エカの集団飛来の発見}

動物園や水族館で飼育されている鳥類が鳥マラリア 原虫に感染して死亡する例が国内外で報告されてい る (Beier and Stoskopf, 1980; Bak et al., 1984; Fix et al., 1988; Murata, 2002; 松本ら 2006; Huijben et al., 2007; Murata et al., 2008). 我が国ではペンギンが鳥マラリア に感染して死亡する例が全国の動物園や水族館で報告さ れており,「ペンギンマラリア」と呼ばれ問題になってい る.この問題の背景には, 我が国の野鳥類と蚊の間に鳥 マラリア原虫の感染環が成立しており, 野鳥類を吸血し て鳥マラリア原虫に感染した媒介蚊がペンギンなど飼育 鳥類を吸血することによって感染が起こっていることが 推測される，鳥マラリア原虫はヒトに感染しないので医 学的な問題はないが, ウエストナイルウイルスのように ヒトにも感染する蚊媒介性の病原体が野鳥で流行した場 合には, ヒトが感染環の中に巻き込まれ，米国で起きた ような大流行になる可能性がある.

野鳥とヒトに共通する蚊媒介性病原体の流行リスクを 評価する上では, 蚊の生息密度に加えて, どのような野 鳥種と蚊種の間に吸血による生態的つながりができてい るのか, 野鳥から吸血する蚊がどの程度ヒトを吸血する かという情報は，もっとも基本的かつ重要な生態的情報 である (Kilpatrick et al., 2005; Molaei et al., 2006; Hamer et al., 2008; Hamer et al., 2009; Kent et al., 2009). 鳥マ ラリアの流行に関する生態学的研究は, このような生態 的情報を収集する上で非常に参考になる (Reeves et al., 1954; Rosen and Reeves, 1954). 特に都市域で流行して いる鳥マラリアの生態的研究は, 都市での蚊媒介性病原 体の流行リスクを考える上で非常に有用であるというこ とができる。

都市域における鳥マラリアの生態調查地として, 東 京都品川区と目黒区の境界に位置する都立林試の森公 園を選んだ。この公園の前身は1900年に農商務省林野 整理局「目黒試験苗圃」として作られ，その後林野庁 「林業試験場」として1978年まで使用されてきた．林 業試験場の移転にともない跡地を整備し現在の「都立 林試の森公園」として公開された，公園内には約900 雨水マスがあり, 幼虫の発生状況を 2003 年から 2005 年 の 3 シーズン調査し, アカイエカ, Culex pipiens pallens Coquillett, ヒトスジシマカ, Aedes albopictus (Skuse), ヤ マトクシヒゲカ, Cx. sasai Kano, Nitahara and Awaya, トラフカクイカ, Lutzia vorax Edwards, オオクロヤブ カ, Armigeres subalbatus (Coquillett), コガタクロウスカ Cx. hayashii Yamadaの6種の生息が確認されている（津 田，投稿中). 公園には林業試験場時代に植えられた樹 木が多数茂り, 野鳥も多く生息しているため鳥マラリア の生態研究に適している. 
鳥マラリアの生態研究を始めるにあたって, 蚊から の鳥マラリア原虫の検出に加えて, 蚊の吸血源動物調 查を行うことを計画した。蚊の吸血源動物種の調査法 は, 種々の動物化を使う方法や抗原抗体反応を利用した Precipiten-test, ELISA法などが使われてきたが, 1990 年代になってDNAの分析結果に基づく分子生物学的 手法が盛んに研究され種々のプライマーが開発された (Silver, 2008). 分析に用いるのは, 吸血して体内に未消 化の動物血液を持っている蚊（吸血蚊）である. 吸血後 何時間経過した個体まで吸血源同定に使えるかという 点に関しては，論文によって結果がやや異なっている； 例えば吸血後 $32 \mathrm{hr}$ まで (Mukabana et al., 2002), 吸血後 24-30 hrまで(Kent and Norris，2005), 吸血後7日まで (Lee et al., 2002), 吸血後3日まで(Boakye et al., 1999). ニワトリマラリアPlasmodium gallinaceumの感染実験 を行ったサンプルでは, 吸血後3日目まで吸血源の同定 が可能で, この期間であれば肉眼で吸血蚊の腹部に未消 化の血液を認めることができた (Kim et al., 2009a).

吸血源動物種の同定にDNAを用いることにはいくつ か長所があるが, 特に鳥マラリアの研究では大きなメ リットがある。鳥マラリア原虫はこれまでに数十種が記 載されている(Valkiunas, 2005). 記載は赤血球に寄生し ているステージの形態観察に基づいて行われている. か つては鳥類種が異なれば寄生しているマラリア原虫種も 異なるという前提に基づいて記載が行われていた。し かし, 最近の研究によれば 1 種類の鳥が複数の原虫に感 染していることが確認されており(Bensch et al., 2000, 2007), これまでの種特異性を前提にしたPlasmodium原 虫の形態分類がどの程度確かなものであるか疑問視され ている(Perkins, 2000). そのため, 最近の野外研究では 鳥マラリア原虫のDNA を抽出し, その塩基配列の違い に基づいて分子分類を行うことが主流になっており, 遺 伝子情報に基づいた検索のためのデータベースも公開さ れている(Bensch et al., 2009). 蚊体内のオーシストやス ポロゾイトの種類を形態的な相違によって同定すること はできないが，この分子生物学的手法を用いれば，発育 ステージに関係なく原虫を区別することができるとい う大きなメリットがある. 吸血源動物種の同定と鳥マ ラリア原虫の同定をともに分子生物学的手法で行えば, DNAの抽出までは同時にできるので分析時間や費用の 節約にもつながる.

分子生物学的分析の材料となる吸血蚊, しかも野外で 暮らす動物を吸血した蚊を多数採集することはかなり 難しい。これまで吸血蚊を採集するためにいろいろな トラップが考案され利用されてきた(Silver, 2008). 北米 のウエストナイルウイルスの大流行に関して近年行わ
れている野外調査では, 吸血蚊の採集に $\mathrm{CO}_{2}$ トラップ, Gravidトラップ, 電動式吸引機, resting boxなどが利 用されている (Kilpatrick et al., 2006a, b; Molaei et al., 2006; Kent and Norris, 2005; Kent et al., 2007; Hamer et al., 2008, 2009). しかしながら, これらの方法によって 採集される吸血蚊の個体数はいずれの方法でも多くはな く, 蚊の吸血嗜好性や原虫感染率を推定するために十分 な個体数を得るには，多数のトラップを複数の調査地に 設置し調査を長期間継続する必要があり, 多大の労力と 時間がかかる。

なんらかのトラップを用いる方法は労力がかかるわり に得られる個体数が少ないことを考慮すると, トラップ を使用せず捕虫網によって採集する方が簡便である。林 試の森公園の植生や蚊の潜伏場所に関してはある程度把 握できていたので，吸血蚊採集には捕虫網を用いること にした，吸血蚊が潜伏に利用する場所は種類によって異 なるが (中尾1959a, b; 緒方ら 1968; 和田, 1970; Service, 1971; Morris, 1981; Irby and Apperson, 1992; BurkettCadena et al., 2008)，草本植物や背の低い灌木の葉裏や 根本, 樹幹の割れ目や樹洞などを利用する種類が知られ ている. 予め林試の森公園を植生の構造と種類の違いに よって大きく3つに区分し, 捕虫網を用いて予備的に休 息蚊の採集を行ったところ，優占種のヒトスジシマカと アカイエカの吸血蚊は大きな樹木が茂り, 林床にシャ ガ, ヤブラン, キチジョウソウなど常緑多年生草本植物 が茂っている場所で比較的多数採集された。そこで，こ の場所を選んで捕虫網による休息蚊の採集を行った。採 集時刻は，夜間に吸血した個体が植物上で休息し，昼間 の休息場所に動く前に採集することを狙って，日の出直 後の 1 時間とした. 調査地の広さや蚊の密度を考慮する と, 毎日多数の吸血蚊がいるとは思われないので, 1 回 の採集時間を長くするよりも短時間の採集を何日間もく りかえす方が得られる吸血蚊数は多くなると考え, 毎週 2〜3回の頻度で採集を繰り返した.

2007 年 4 月から 12 月の期間に行った採集結果を Table 1 に示した。捕虫網採集では吸血蚊だけでなく未吸血蚊 も採集される。そのため, 合計 11 種類 27,116 個体と予 想外に多くの蚊が採集された。このうち吸血蚊は，合 計732個体であった。この採集でもっとも興味深い結 果は, Table 1 の最上段に示されているように, 東京の 市街地にある公園にもかかわらず，コガタアカイエカ, Cx. tritaeniorhynchus Giles，が非常に多数採集されたこ とである。しかも採集された時期は9月から 12 月とい う, これまでの調查報告から考えて季節はずれの時期で あり,これはまったく予想外の結果であった(Fig. 1). 
Table 1. Results of sweeping collection of resting mosquitoes conducted at Rinshi-no-mori park, Tokyo, Japan from April to December 2007.

\begin{tabular}{|c|c|c|c|c|c|c|c|c|c|c|c|}
\hline Species & Apr & May & Jun & Jul & Aug & Sep & Oct & Nov & Dec & Total & $\begin{array}{c}\text { \# blood-fed } \\
(\%)\end{array}$ \\
\hline Cx. tritaeniorhynchus & & & 1 & 5 & 16 & 612 & 14,341 & 1,900 & 17 & 16,892 & $4(0.02)$ \\
\hline Ae. albopictus & & 42 & 131 & 1,006 & 3,223 & 1,699 & 1,080 & 65 & 2 & 7,248 & $436(6)$ \\
\hline Cx. pipiens gr. & 3 & 123 & 310 & 365 & 284 & 126 & 654 & 217 & 10 & 2,092 & $249(12)$ \\
\hline Cx. sasai & 2 & 2 & 6 & 2 & & & 268 & 211 & 6 & 497 & $18(4)$ \\
\hline Lt. vorax & & & & 10 & 59 & 18 & 128 & 50 & 1 & 266 & $23(9)$ \\
\hline Or. anopheloides & & & & & 42 & 7 & 3 & & & 52 & $2(4)$ \\
\hline Ar. subalbatus & & 1 & 1 & 7 & 17 & & 1 & & & 27 & $0(0)$ \\
\hline Cx. orientalis & & & & & & & 16 & & & 16 & $0(0)$ \\
\hline Cx. rubithoracis & & & & & & & 12 & 1 & & 13 & $0(0)$ \\
\hline Cx. bitaeniorhynchus & & & 1 & 2 & & 5 & 1 & & & 9 & $0(0)$ \\
\hline Cx. inatomii & & & & & & & 4 & & & 4 & $0(0)$ \\
\hline
\end{tabular}
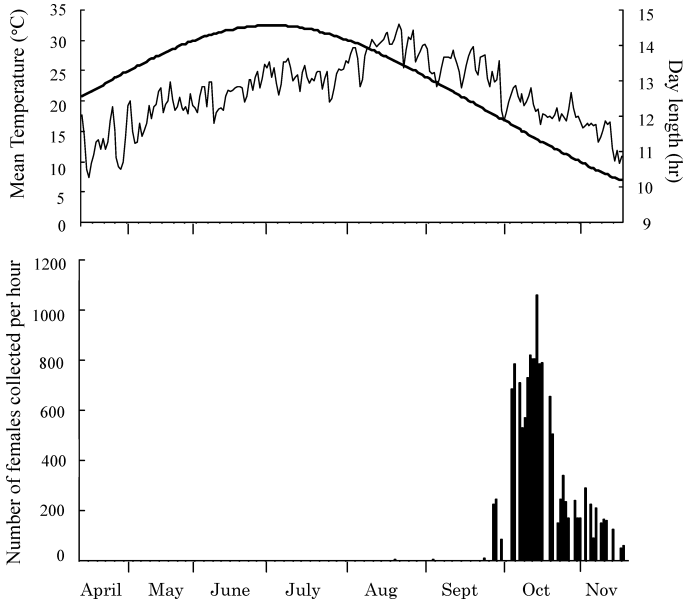

Fig. 1. Number of Cx. tritaeniorhynchus females collected from vegetation by sweeping and daily changes in average temperature and the day length in Tokyo, Japan from April to November 2007.

\section{（2）コガタカイエカの季節消長に関するこれまでの見解}

コガタアカイエカの生態に関しては, 過去に多くの研 究が我が国で行われている; 成虫の発生消長 (Fukumi et al., 1975; Wada et al., 1975; Mogi, 1978; Watanabe et al., 1990; Matsuzaki, 1990; Takagi et al., 1995), 休息場所（緒 方ら, 1968; 和田, 1970), 分散 (Wada et al., 1969), 吸 血様式(Mwandawiro et al., 1999), 吸血時間 (Mogi et al., 1970), 光周反応 (Oda and Wada, 1973; Oda et al., 1978), 越冬生態 (Omori et al., 1965a, b; Ito et al., 1986; Wada et al., 1967, 1973), 日本脳炎ウイルスの媒介生態(Buescher and Scherer, 1959; Hayashi et al., 1975; Scherer et al., 1959). これらの研究結果に基づいて成虫の季節消長を
以下のようにまとめることができる.コガタアカイエ カの繁殖は九州地方では3月末にはじまり9月末から 10 月初めに終了する。動物舎に設置したライトトラップ での調査によると, 繁殖の開始時期は北の地域ほど遅 くなるが, 捕獲個体数が9月末に激減することは各地の 調査で一致している。このような季節消長はわが国に 限らず他の温帯地方, 韓国や中国でもほぼ同様である. (Fukumi et al., 1975; Wada et al., 1975; Reisen et al. 1976; Matsuzaki, 1990; Watanabe et al., 1990; Ming et al., 1993; Takagi et al., 1995; Ming and Xue, 1996; Kim et al., 1999). 9月末から 10 月に羽化した成虫は卵巣が末発達で吸血 せず，いわゆる繁殖休眠の状態で翌春まで越冬する．羽 化成虫か繁殖休眠に入る条件としては幼虫期の気温と日 長が重要であり, 仙台系統を $24^{\circ} \mathrm{C}$, 日長 13 時間 30 分の 組み合わせで飼育した場合 $99.2 \%$ が繁殖休眠に入り，長 崎系統の臨界日長は13時間という調查結果がある（和 田ら未発表)。東京の個体群の臨界日長はこの間にある と考えるのが妥当であろう. 実際には日の出と日没の前 後に 30 分ほどの薄明薄暮の時期があるので, これを考 慮して生物学的日長（日の出から日没までの時間に薄明 薄暮 1 時間を加えた值）を求めるのが実際的である．生 物学的日長が 13 時間 30 分および 13 時間になるのは東京 では9月 13 日および9月 27 日で, この時期を境にして 繁殖世代から休眠世代への切り替わりが徐々に進展す る. Kawai (1969)によれば，長崎で9月末から 10 月上旬 に産卵された卵は孵化して，その後10月末までに50\% 以上が羽化し, 羽化成虫はすべて繁殖休眠に入った。さ らに10月中旬以降に産卵された卵は孵化してその一部 （30\%程度）は成虫まで発育するが，多くは12月までに 幼虫で死亡している. 
Table 2. Results of sweeping collection of Cx. tritaeniorhynchus at Rinshi-no-mori Park, Tokyo, Japan during 2007 to 2010.

\begin{tabular}{lrrrr}
\hline \hline & 2007 & 2008 & 2009 & 2010 \\
\hline Overwintered females & - & 11 & 211 & 12 \\
Total females collected & 14,090 & 27,471 & 2,666 & 9,093 \\
Total males collected & 2,802 & 1,717 & 662 & 1,150 \\
Total adults & 16,892 & 29,188 & 3,328 & 10,243 \\
Total hrs examined & 45 & 42 & 36 & 30 \\
No females/hr & 375 & 694 & 93 & 341 \\
Proportion of females & 83 & 94 & 80 & 89 \\
Parity (\%) & 4 & 3 & 7 & 2 \\
Proportion diapausing & 85 & 97 & 93 & 90 \\
\hline
\end{tabular}

${ }^{1}$ Total number of females collected in March and April.

（3）林試の森公園へのコガタアカイエカの飛来と越冬

過去の調査で明らかになったコガタアカイエカの季節 消長を踏まえて, 表 1 に示したコガタアカイエカの捕獲 個体数の推移を見ると, 飛来した個体は 10 月と 11 月に 集中しており，越冬世代であると予想された。そこで 飛来した個体（約 200 個体）を解剖し濾胞の発育状態を 調べたところ, 多くの個体は濾胞が小さく繁殖休眠状 態に入っていることがわかった(Tsuda and Kim, 2008, 2010). 林試の森への集団飛来は2007年以降継続して調 べているが, 毎年ほぼ同じ時期に飛来が観察されてい る. Tsuda and Kim (2010)の報告に2009年と2010年の 調査結果を加えて Table 2 に示した. 調査した 4 年間で 飛来総数は2009年が最も少なく3,328個体，2008年が 最も多く約 9 倍の 29,188 個体であった。飛来個体の中に は雄も含まれているが, どの年も雌の方がはるかに多 く, 捕獲個体全体の 83〜 94\%を占めていた. 繁殖休眠 に入っていると判定された個体の割合は，85～97\%で， 少なくとも 1 回は産卵した経験のある雌の割合は全体の わずか 2 〜\%であった.

濾胞の発育状態を調べるために飛来個体を解剖する と, 腹部に多量の油滴を蓄えた個体がいることに気づ く. 飛来数が最も多い10月の採集個体について, 油滴 量を微量 $(+)$ から著しく多量 $(+++++)$ まで, 5段階に分 けて記録し初旬, 中旬, 下旬の3期に分けて集計して Fig. 2 に頻度分布を示した. 観察した 3 シーズンの結果 はほぼ同様の傾向を示していた。10月上旬には油滴量 が2番目に少ない $(++)$ 個体の頻度が最も高く，著しく 多い個体 $(+++++)$ はわずかである。これに対して10月 下旬になると油滴量が多い $(++++)$ 個体の頻度が最も高 く, 著しく多い $(+++++)$ 個体の比率も高い。このよう に季節の進行に伴って体内の脂肪の蓄積が進んでいるこ とがわかる，越冬成虫が体内に多量の脂肪を蓄積してい るという報告は他の種類の蚊でも報告されており, 冬
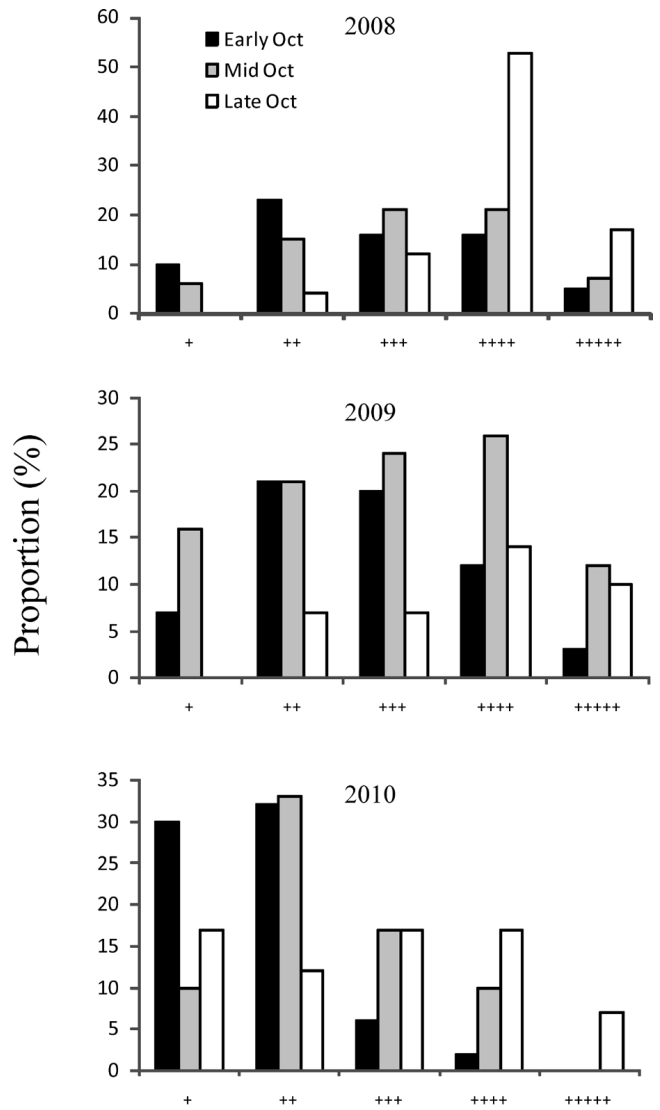

Fat body class

Fig. 2. Fat body development in females $C x$. tritaeniorhynchus collected from vegetation in October 2008, 2009 and 2010 in Tokyo.

季の生存に有利であると考えられている(Kliewer et al., 1969; Nelson, 1971; Mitchell, 1988).

2007 年と 2008 年には林試の森公園で多数の飛来が確 認された 10 月に，東京都内と千葉県内の公園でも調査 
を行い, 調査した公園のほとんどで同じょうにコガタ アカイエカの飛来が確認された (Tsuda and Kim, 2008). 林試の森公園でコガタアカイエカが多数採集される場所 には, シャガ, ヤブラン, キチジョウソウが茂ってい る. 笹やイネ科の 1 年草が茂っているような場所ではほ とんど捕獲されない. 他の公園の調査でも, ヤブランが 茂っている場所でコガタアカイエカがよく採集される傾 向がある. ヤブランやキチジョウソウは常緑広葉樹林の 林床に生育する植物である(平田ら, 2006). 林試の森 公園の採集場所も, シイなど常緑広葉樹の樹冠で覆われ た林床で, 常緑の低木（アオキやャツデなど）に混じっ てこれらの植物が茂っている。2008年に調査した千葉 県の泉自然公園は, 我々がこれまでに調査した限りで は, 林試の森公園の次に飛来個体数が多い公園である. この泉自然公園でコガタアカイエカが採集される場所も 大きな樹の樹冠で覆われている点は林試の森公園と共通 していたが, 林床の植生は林試の森とは異なり, シダ植 物やツタで覆われていた。

これまでの調査でコガタアカイエカが多数採集されて いる場所の植生から考えて, 越冬世代成虫は常緑広葉樹 林を目指して移動していると推察している. 適当な常緑 広葉樹林に飛来した直後は, 成虫の脂肪の蓄積量は少な い. その後徐々に脂肪の蓄積が進行する.このころ常緑 広葉樹林の林床では, ヤブランやキチジョウソウなどの 多年生草本植物が開化期を迎えている. 恐らくこれらの 花などから吸蜜した糖分を脂肪として蓄積しているもの と思われる. 1 個体に注目した時, 季節移動は 1 回きり なのか, それとも移動期間が存在しその期間中は何度も 移動を繰り返すのか, どちらであるかは今のところわか らない. たまたま飛来した林の条件が良ければそのまま 留まり, 条件が悪ければ移動してよりよい場所を探すと 推測している.9月から 10月にかけての期間, 蚊以外に クモ（カニグモやハエトリグモなど）の幼虫や若虫が多 数捕獲され, ネットの中で盛んに蚊を捕食する。これら のクモは体が小さく狭い隙間にも大り込むことができる ので，その活発な動きから考えて蚊がクモに捕食される リスクはかなり大きいと予想される。したがって, 気温 が高く活動可能な時期には, クモが同所的に生活してい る場所では蚊がクモの捕食を逃れることができるよう に, 狭い空間には留まっていないだろうと推察してい る. クモ以外の天敵としてアリが考えられるが, コガタ アカイエカが捕獲されるような場所ではアリが一緒に捕 獲されることは稀であり，アリによる捕食は問題になら ないように思われる.

常緑広葉樹林を目指した移動には大きな意味がある. 森林の成立を左右する大きな要因は温度条件であり, 常
緑樹の分布限界を制限しているのは冬の低温である（大 沢, 1993). 常緑広葉樹の場合, 地温が $3 \sim 5^{\circ} \mathrm{C}$ 以下に下 がると根の吸水力が低下して乾燥が厳しい冬には乾燥害 を受けることが知られており（酒井，1975）, 常緑広葉 樹の林は最寒月の平均気温が $5^{\circ} \mathrm{C}$ 以上の地域に育つとさ れている. したがって, 常緑広葉樹林に移動したコガタ アカイエカには $5^{\circ} \mathrm{C}$ 以上の冬季平均気温が確保され, 冬 季の生存に重要な意味を持つと考えられる. 東日本ま で分布する代表的な常緑広葉樹であるスダジイの分布 北限線は最寒月の平均気温 $=2{ }^{\circ} \mathrm{C}$ されている（吉岡, 1954). シイノキの分布北限地域では, 大きな林ではな く数本のシイノキが生育しヤブランやキチジョウソウな どの林床植物がある程度茂っていれば，そこもコガタア カイエカの越冬場所として利用される可能性があるよう に思われる。

翌春に越冬した成虫が現れる時期は，1965から 1971 年にかけて長崎で行われた研究によれば, 1 月 1 日から の日平均気温の累積值が 651 日度に達する 3 月下旬で ある (Wada et al. 1973). 林試の森公園の調査で越冬し たコガタアカイエカが採れ始めた日は2008年4月 1 日 (697.8日度)，2009年3月18日（597.4日度），2010年3 月 16 日（549.3日度），2011年4月 2 日（628日度）であ り, 平均累積温量は618.1日度であるから, 長崎とほぼ 同様の生理的過程を経て休眠から覚醒していることを予 想させる. 2008年と 2009年には平均気温の日変化から 考えて, 恐らく越冬中と思われる個体が合計 4 個体採集 されている（2008年1月30日，2月23日，2009年2月 15 日，3月 7 日に各 1 個体). 3 月中旬〜 4 月にかけて林 試の森公園で採集されたコガタアカイエカは, 2008年 11 雌，2009年 212 雌，2010年 12 雌であった．前年の飛 来個体数に比較するとかなり少ない個体数であるが, 飛 来した個体の一部がこの調查地周辺に留まり, 翌春まで 生存していたことは確かめられた。越冬したコガタア カイエカ成虫は林試の森公園以外では, 泉自然公園で 2009年4月 8 日に 12 雌がハマダライエカ, Cx. orientalis Edwards, (1 雌) と共に採集されている (Tsuda and Kim, 2010).

コガタアカイエカ成虫の冬期の生存率に関する野外調 查はこれまでまったく行われていない. その最大の理 由はコガタアカイエカの越冬場所が不明であったため である. 冬季のコガタアカイエカの採集に関しては過 去に3つの報告がある. Bullock et al. (1959)は1957年 9 月, 11 月, 12 月, 1958 年 1 月に, 千葉県市川市（新浜） の藪 (brush) や松束などで数個体ずつ合計 10 個体, 原田 ら (1962)が 1962年12月と 1963年1月に城ケ島のロック プール水面とブッシュで覆われた溝で合計 4 個体, 和田 
ら (1968)が1967年1月に伊豆半島の石切り場などで合 計 60 個体を採集している. 越年に関する実験的な検討 は, Omori et al. (1965a)が行っている. 実験室で羽化さ せた成虫約 200 対を $2 \%$ 砂糖水と共にケージに入れ, 気 温や明るさの異なる 3 つ場所（地下室, 動物舎内, 北側 階段踊り場）に設置して，10月末から翌春までの生存個 体数を調査している. 幼虫飼育時の日長条件に関しては 記述されていないが, 吸血させた成虫とさせなかった成 虫の比較を行っていることから, 実験に用いた成虫は休 眠成虫ではなかったと思われる。これら成虫の翌春 4 月 初めまでの生存率を生存曲線から読み取ると， 5〜 10\% で,もっとも長命な個体は6月まで生存していた. 大森 らはこの実験結果に基づいて, 越冬には昼夜を通じて暗 黒な条件が重要で, 気温の高低や温湿度の変化度合いは その次に重要な要因であると結論している.

林試の森公園に飛来した個体の場合も, 実際の越冬場 所がどこであるかは残念ながらいまだにわかっていな い. そのため冬季生存率の野外での推定はできていな い.しかし, Omori et al. (1965a)と似た発想で実験的 な条件下での生存率を調べてみた。2010年11月9日に 林試の森公園で採集された105個体を実験に用いた。採 集時期から考えて供試個体はほとんどが繁殖休眠に入っ ていたと推測される. $30 \mathrm{~cm}$ 立方のプラスチック製飼育 ケージを用い, 実際にコガタアカイエカが採集される場 所を模して，ケージ内にキチジョウソウ 1 株の鉢植えを 設置した。ケージの床面は落ち葉や朽木片で覆い，5\% 砂糖水 $10 \mathrm{ml}$ に脱脂綿の芯を刺したボトルと熟した柿を 設置した。熟し柿はこの時期に野外で利用可能な吸蜜源 の一つとして選んだ. ケージの設置場所は北に面した屋 内で空際に設置した。暖房設備はない，データロガー を使って 2 時間ごとに気温と湿度を記録した。11月から 3 月初めまでの湿度は平均 $58 \%$ （最低 $24 \%$, 最高 $76 \%$ ） であった. 日平均気温と生存個体数をFig. 3 に示した. ケージ設置場所の調查期間全体の平均気温は $10.8^{\circ} \mathrm{C}$ (最 低 $7.8^{\circ} \mathrm{C}$, 最高 $15.1^{\circ} \mathrm{C}$ ) で, これに対して最も近い気象 観測地点の平均気温は $6.0^{\circ} \mathrm{C}$ (最低 $2.0^{\circ} \mathrm{C}$, 最高 $14.1^{\circ} \mathrm{C}$ ) と約 $5^{\circ} \mathrm{C}$ の差が認められた. ケージ設置場所の日平均 気温が $5{ }^{\circ} \mathrm{C}$ 以下になることはなく, 1 月 1 日からの日平 均気温の累積值が 614.8 日度を上回ったのは2月26日 （619.4日度）であった。したがって，この条件下で3月 初めまで生存していた個体はすでに休眠から覚醒してい たと推測される.この時点で生存していた個体は3個体 で, 生存率は 0.029 (3/105)であった. 野外の気温との 差を考慮すると, 野外の越冬場所における生存率がこの 值を上回るとは考えにくい.

冬季の生存率が 0.029 より低いだろうという推測の意

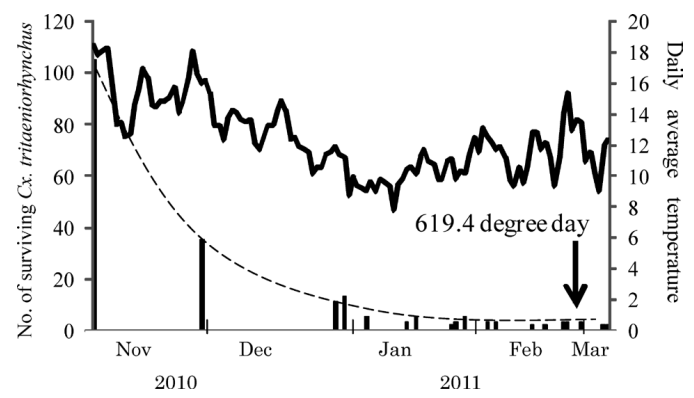

Fig. 3. Survival curve (broken line) of diapausing Cx. tritaeniorhynchus collected in October 2010 and kept under indoor conditions without temperature regulation. A total of 105 females were collected from vegetation and kept in a cage with a 5\% sugar solution from November 2010 to March 2011. The air temperature in the rearing cage was recorded every $2 \mathrm{hr}$ and the daily changes in average temperature during the study period was calculated (thick line).

味を考察するとき, 関東地方がコガタアカイエカの地理 的分布の北限に近い地域であることを理解しておくこと が重要である。コガタアカイエカは東南アジアを中心に 熱帯から温帯まで非常に広い地域に分布しており, 熱帯 地方恐らく東南アジアに起源を持つと考えるのが妥当と 思われる. 一般に昆虫類が熱帯から温帯に分布を広げる 過程で大きな障壁となるのは, 低温で乾燥する冬の存在 である．本来南方系のコガタアカイエカが繁殖休眠とい う生理的な適応戦略を採用することによって低温乾燥の 冬を生き延びることに成功し, 温帯地方にまで分布を拡 大したことは明らかである。しかしながら気象条件がよ り厳しい分布の北限地域では繁殖休眠によって冬季に高 い生存率を達成することは難しく, 個体群の存続にとっ て越冬が現在でもなお重大な生態的問題であると考える のが妥当なように思われる。冬の気象条件がもう少し緩 やかな西南日本で, コガタアカイエカの越冬生態を調査 することが望まれる。

\section{（4）鳥マラリア原虫の媒介蚊と感染環}

鳥マラリア原虫の媒介蚊としてこれまで報告されて いるのは, イエカ属, ヤブカ属, ヌマカ属, クロヤブ カ属, 八ボシカ属など多種類に及ぶ(Valkiunas, 2005). これらの報告には実験的に感染させた例が含まれるた め, 野外で実際に鳥マラリア原虫を媒介している種類 はこのうちの一部と考えられる。海外の鳥マラリア媒 介蚊の野外研究は1950年代から行われているが，けっ して多くはない（例えばReeves et al., 1954; Rosen and Reeves, 1954; Applegate et al., 1971; Gogolin and Freier, 
1986; Huijben, 2007; Massey et al., 2007; Ishtiaq et al., 2008; Njabo et al., 2009). 鳥マラリア媒介蚊について比 較的詳しい調査が行われているのはハワイ諸島で, 媒介 蚊であるネッタイイエカ, Cx. quinquefasciatus Say と鳥 マラリア原虫の侵入によって, 固有の野鳥種が大きな影 響を受けている (van Riper et al., 1986; van Riper, 1991; Ahumada et al., 2004; Reiter and LaPointe, 2007; Aruch et al., 2007).

我が国の野鳥の鳥マラリア原虫感染状況に関する研究 は，古くは加納(1950)に始まる。 Murata (2002)は1988 年から 2001 年の 13 年間に治療のために動物園に持ち込 まれた傷病野鳥701例について血液寄生性原虫の感染状 況をまとめ, 調查した $10.6 \%$ で感染が認められたと報告 している。さらに蚊によって媒介される Plasmodium属 の鳥マラリア原虫に感染していた野鳥としては, キジバ ト, Streptopelia orientalis, タシギ, Gallinago gallinago, ゴイサギ, Nycticorax nicticorax, ヒヨドリ, Hypsipetes amaurotis, ハシブトガラス, Corvus macrorhynchos, が リストされている. 鳥マラリア原虫に感染したこれら の野鳥を吸血した蚊がペンギンを吸血し, ペンギンマ ラリアを引き起こしていると考えられることから, 我 が国の動物園を対象とした鳥マラリア原虫の媒介蚊に 関する調查が行われている（Ejiri et al, 2009, 2011, 松本 ら，2006). また, 野鳥における感染環の調査を目的と して, 郊外に位置する大学農場や渡り鳥の飛来地, 都市 部の公園などを対象にした媒介蚊相調査と鳥マラリア 原虫の検出も行われている（Ejiri et al., 2008; Kim et al., 2009a, b; 城谷ら, 2009; Tsuda et al., 2009a, b; Kim and Tsuda, 2010). これらの研究の中から, Kim and Tsuda (2010)を中心に, 林試の森公園で採集された蚊サンプルに 基づいた鳥マラリア原虫の分子生態学的研究を紹介する.

Table 1の右端の欄に2007年4月から 12 月に採集され た吸血蚊の個体数を示した. 多数の吸血蚊が採集され たのは, ヒトスジシマカ, アカイエカ, ヤマトクシヒ ゲカ, トラフカクイカの 4 種類であった. 中でもヒトス ジシマカとアカイエカはそれぞれ436個体, 249 個体と 多数のサンプルが集まった。 ヒトスジシマカは2003年, 2004年に同じ採集場所で得られた 86 の吸血蚊サンプル を分析して吸血源動物を同定したところ，92\%が哺乳類 を吸血しており, 鳥由来の血液を吸血していた個体はわ ずかに5\%であった．他の地域の分析結果と総合して考 えると, ヒトスジシマカが野鳥から吸血する機会は非常 に少ないことがわかった(Sawabe et al., 2010). これに 対してアカイエカは, 我が国の動物園や渡り鳥飛来地で 行った調査の結果, 鳥マラリア原虫のもっとも重要な媒 介蚊であることが示唆されている（松本ら, 2006, Ejiri et al, 2009, 2011, Kim et al., 2009b)． そこで鳥マラリア原 虫の分析の対象として, アカイエカを選んだ。

\section{（5）蚊体内での鳥マラリア原虫の発育と吸血蚊からの原 虫検出結果の対応関係}

鳥マラリア原虫を媒介できる蚊の種類は限られる. また鳥マラリア原虫には数十種が知られており, それ ぞれの原虫種によって媒介蚊の種類は異なっている (Valkiunas, 2005). これを蚊の立場からいいかえると， 媒介できる鳥マラリア原虫もあれば媒介できないものも ある. 最近の鳥マラリア原虫の研究は, ある地域の鳥マ ラリア原虫がとても多様であることや，1種類の鳥類が 複数種の原虫の宿主になっていることを報告している (Bensch et al., 2000, 2007; Ricklefs et al., 2005; Fallon et al., 2005). したがってある調査地の分析対象の蚊を 1 種 類に限っても，媒介できる原虫と媒介できない原虫が複 数種存在していることが予想される.このような状況の 中で鳥マラリア原虫の感染環を明らかにするためには, 蚊から検出された原虫のどれが媒介可能な原虫で, どれ がそうでないのかを区別し，さらに検出された原虫の宿 主鳥類を推測する必要がある.

吸血蚊を分析する際に1個体を胸部と腹部に二分し, 腹部からは血液源動物の同定と鳥マラリア原虫の検出 を行い, 胸部からは鳥マラリア原虫の検出を行うこと で，媒介可能な原虫とそうでない原虫を推測できないか と考えた。蚊が媒介できる鳥マラリア原虫は, 血液と共 に蚊に取り込まれた後, 蚊の中腸壁でオーシストを形成 し，スポロゾイトの生産を行う。この発育段階までは原 虫は蚊の腹部にのみ存在しているはずである。その後 オーシストが破裂してスポロゾイトが体内に泳ぎ出す と, 胸部や唾液腺に原虫が移動するので, PCRによっ て原虫のDNAを増幅させると蚊の腹部だけでなく胸部 からも原虫が検出されるはずである。一方鳥マラリア原 虫を媒介できない蚊の場合は, 感染した鳥から原虫を取 りこんでも，オーシストが形成されないため，原虫が検 出されるのは腹部に感染血液が残っている短期間に限ら れ，胸部から検出されることはないと考えられる。これ らの予測が実際に成り立っているかどうかを, ニワトリ マラリア, P. gallinaceum, とネッタイシマカAe. aegypti (Linnaeus) を用いた感染実験によって調べた (Kim et al., 2009a). その結果, 感染させたニワトリを吸血したネッ タイシマカは, 予想通り吸血後 8 日目までは腹部のみで 原虫のDNAが増幅されたが, 9日目以降には, 腹部と 胸部の両方で原虫DNAが増幅されることが確かめられ た。したがって, 蚊の胸部から検出される鳥マラリア原 虫は, その種類の蚊によって媒介されている可能性が高 
いと考えてもよいと結論した。ただし，ニワトリマラリ アを媒介できないアカイエカを用いた比較実験で, 胸部 から原虫DNAが検出される場合があることから, 野外 捕集蚊からの鳥マラリア原虫検出結果の考察は, 他の情 報を加味して注意深く行う必要があると考えている。

（6）林試の森公園のアカイエカからの鳥マラリア原虫の 検出

アカイエカのサンプルからの原虫検出の結果は興 味深い. 林試の森公園で採集された未吸血蚊 (un-fed mosquito, 吸血しておらず体内に動物の血液を持たない 蚊）643個体は腹部のみを用いて，1-10個体を 1 プール として，合計71プールに分けて分析した．その結果 22 プール $(31 \%)$ で原虫のDNAが検出された. 原虫が検出 された 10 プールをランダムに選び, 取り分けておいた 胸部を1個体ずつ分析して, 原虫陽性個体を調べた結 果，1プールあたり平均 1.5 匹の原虫陽性個体が含まれ ていた。この值から分析に用いた643個体に含まれて いた原虫陽性個体数を求め, 感染蚊率を推定したとこ ろ 5\%であった. アカイエカ（未吸血蚊）の原虫感染率 は, 2007年に実施した東京港野鳥公園の場合, プール

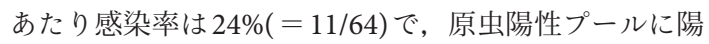
性個体が 1 個体含まれていると仮定して求めた感染蚊率 は, 3\%であった(Kim et al., 2009b). ヒトのマラリア原 虫の場合, 流行地における感染蚊率は数\%から $10 \%$ 程 度であることが知られている（例えば, Kent et al., 2007; Krafsur, 1977; Rao, 1984; Trung et al., 2004; Maekawa et al., 2009). したがって媒介蚊の感染蚊率から推測する
と，鳥マラリアの流行はかなり盛んであると考えられ る.この結果は温帯地方であっても蚊によって媒介され る病原体が効率よく伝播されていることを示しており, 蚊が病気を媒介するのは熱帯地方に限らないことが再確 認される。なお, ベネズエラで野鳥の鳥マラリア感染率 と媒介蚊の原虫陽性率を調心゙た研究では，コウノトリ 目の 23 種類の感染率が親鳥 $5.8 \%$, 雛 $53.6 \%$, ガン・カ モ類など 9 種類の鳥では親鳥 $6.5 \%$, 雛 $26.9 \%$ で，媒介蚊 とされるAedeomyia squamipennis (Lynch Arribálzaga) の感染蚊率は伝播のピーク時に $4.5 \%$ に達しており，大 流行(Holoendemic)の状態であると報告されている (Gabaldon and Ulloa, 1980).

吸血源動物の同定結果と鳥マラリア原虫の検出結果を Table 3 に示した. 2007年5月から 2008年5月にかけて 採集された 371 個体の吸血蚊のうち, 腹部に残っていた 血液から DNA を抽出しその塩基配列から動物の種類を 推定できたのは，220個体であった。分析に用いた吸血 蚊の中には産卵直前の個体 (Gravid) も含まれており, こ のようなサンプルではDNAを得ることが難しく吸血源 動物を同定できなかった。同定された動物の種類は 1 個 体を除いてすべて鳥類であった。ヒトを吸血していた個 体はわずかに 1 個体だけであった．同定された鳥類は 13 種類で, 吸血された頻度が高かったのは, ハシブトガラ ス (63.8\%), スズメ(Passer montanus) (12.8\%), シジュウ カラ (Parus major) (6.8\%)で，3種類を合わせた構成割合 は $83.4 \%$ に達した.これらはいずれも留鳥で, ほぼ一年 中この調査地で生活している。他に吸血源として同定さ れた野鳥にはシメ(Coccothraustes coccothraustes), シロ

Table 3. Results of blood-meal identification and avian malaria parasite prevalence in blood-fed Cx. pipiens pallens collected in Rinshi-no-mori park, Tokyo, Japan from May 2007 to May 2008.

\begin{tabular}{lccc}
\hline \multicolumn{1}{c}{ Blood-source } & No. of & Plasmodium & Parasite \\
& mosquitoes & + & prevalence (\%) \\
\hline Jungle crow (Corvus macrorhynchos) & 141 & 39 & 29.1 \\
Tree sparrow (Passer montanus) & 28 & 6 & 21.4 \\
Great tit (Parus major) & 15 & 6 & 40 \\
Dusky thrush (Turdus naumanni) & 9 & 0 & 0 \\
Japanese white-eye (Zosterops japonicus) & 6 & 1 & 16.7 \\
Hawfinch (Coccothraustes coccothraustes) & 5 & 1 & 20 \\
Oriental turtle-dove (Streptopelia orientalis) & 3 & 0 & 0 \\
White-cheeked starling (Sturnus cineraceus) & 4 & 0 & 0 \\
Pale thrush (T. pallidus) & 3 & 0 & 0 \\
Azure-winged magpie (Cyanopica cyanus) & 2 & 0 & 0 \\
Brown-eared bulbul (Microscelis amaurotis) & 1 & 0 & 0 \\
Grey-bunting (Emberiza variabilis) & 1 & 0 & 0 \\
Eyebrowed thrush (T. obscurus) & 1 & 0 & 0 \\
Human (Homo sapiens) & 1 & 0 & 0 \\
Total & 220 & 53 & 24.1 \\
\hline
\end{tabular}


ハラ(Turdus pallidus), マミチャジナイ(T. obscurus)のよ うな渡り鳥も含まれていた，鳥マラリア原虫が検出され たのは 13 種の野鳥のうち 5 種類で, 原虫陽性率は 16.7 〜 40\%と鳥の種類によって違いが見られた.

\section{（7）検出された鳥マラリア原虫の系統}

アカイエカから検出された鳥マラリア原虫のDNAを 抽出し, チトクローム $\mathrm{b}$ 遺伝子の塩基配列を比較したと ころ, 互いに配列が異なる合計 10 系統の鳥マラリア原 虫が見つかった.1種類の蚊から検出される原虫系統の 数がこれほど多いとは予測していなかった。吸血蚊の胸 部と腹部に分けて検出された鳥マラリア原虫の系統を整 理したところ,これら10系統の中で胸部と腹部の両方 から検出されているのは3系統であった. またこれら 3 系統が検出された個体が吸血していた野鳥の種類は, 八 シブトガラスとスズメであった。これらの結果から， 3 系統は少なくともハシブトガラスとスズメを宿主として アカイエカによって媒介されていると結論した.

感染環が成立していると推測される3系統の中で, CXPIP09と呼ばれる系統はこの調査地の優占種で, Ejiri et al. (2009), Kim et al. (2009b)によってわが国の ほかの調査地でも検出されているが, 今のところ海外 では報告がない。したがって, 本邦産の蚊と留鳥に適 応した系統である可能性が高い.これに対して, SGS1, PADOM02 と呼ばれる2系統は海外でも報告されている 分布の広い種類である. 恐らく海外で感染した渡り鳥に よって持ち込まれ, 新しい媒介蚊としてアカイエカとの 間に親和性を確立し, ハシブトガラスやスズメとの寄生 関係を成り立たせることに成功したのだろう。これに対 して, 残りの7系統は吸血蚊の腹部からのみ検出されて おり，吸血源となった鳥が感染していたと推測してい る.これらの系統は胸部から検出されていないことか ら, 少なくともアカイエカとの間にはまだ親和性が確立 されていないと考えられる.このように鳥によって持ち 込まれていても, 今のところ定着に成功していないと思 われる系統が見出されることは, 鳥マラリア原虫以外の 病原体の野鳥による持込の可能性をも示唆しており重要 である。

\section{（8）アカイエカの吸血源動物の種類と季節変化}

吸血源動物の調查結果を月単位でまとめて, 吸血パ ターン (feeding pattern)の季節変化を見ると，春先 3 月， 4月には冬鳥を吸血している個体が70～80\%を占めて いる. その後ハシブトガラスやスズメ, 特にハシブトガ ラスの構成割合が著しく高くなり，9月には吸血源動物 全体の約90\%に達した。4月から8月は温帯地方の野鳥
の繁殖期であり, 林試の森公園でもシジュウカラやスズ メ, ハシブトガラスの営巣が行われている. 営巣中の親 鳥や雛は吸血されやすいと思われるが，アカイエカは吸 血源となる野鳥の種類相の季節変化や行動・生態の変化 に対応させて, 吸血する動物の種類を変えていることが はっきり示されている.アカイエカはその時々に利用し やすい動物を吸血して効率よく繁殖していると考えられ るが，このような習性がハシブトガラスやスズメを宿主 動物とする鳥マラリア原虫系統の感染環を支えているの である。

\section{（9）蚊によって媒介される病原体の侵入・定着の生態学 的基盤}

これまで行われた吸血源動物の調査結果に基づいて, 林試の森公園に生息しているアカイエカ, ヤマトクシヒ ゲカ, ヒトスジシマカと野鳥などの野生動物の生態的関 係を以下のようにまとめることができる．アカイエカは 鳥嗜好性が極めて高く $(99.5 \%)$, 少なくとも 13 種類の野 鳥から吸血していることがわかった。また，ヤマトクシ ヒゲカも調查した吸血蚊の $86.7 \%$ が5 種の野鳥を吸血し ており, アカイエカと同様に鳥嗜好性が高い(Kim et al., 2009a).これに対してヒトスジシマカはヒトを含む哺乳 類を $92 \%$ の個体が吸血しており，野鳥を吸血していた 個体はわずかに $5 \%$ であった。この公園に生息する蚊と 動物は, 蚊の吸血嗜好性に依存したいろいろな強さで間 接的なつながりを持っている. そして野鳥とのつながり が強いアカイエカやヤマトクシヒゲカが, 野鳥の鳥マラ リア原虫の伝播や存続にかかわっている，つまり，都市 域に生息する蚊の中には, 吸血習性によって多様な野生 動物（野鳥）と接触し，その生態的関係を通じて実際に 野鳥由来の病原体を伝播している種類が存在することが 明らかになった。このことは，蚊を媒介者として人と動 物の間で伝播する病原体が侵入・定着し流行するための 生態学的条件が, 既に都市域の公園や緑地に整っている ことを示唆しており, 媒介蚊の生態調查の重要性を再認 識させている.

\section{謝辞}

これまで私の研究をいろいろな形で支えてくださっ た, 諸先輩や同僚, 国内外の共同研究者の方々に心から お礼を申し上げます．特に長崎大学熱帯医学研究所で疾 病媒介蚊の生態研究を始めた当時, 素人の私を一から指 導してくださった和田義人博士，高木正洋博士に感謝い たします。また，国立感染症研究所において媒介蚊研究 を継続できたのは, 小林睦生博士をはじめ昆虫医科学部 の皆様のご理解とご協力によります。 心から感謝いたし 
ます。都市域の疾病媒介蚊調査を継続するにあたって, 鳥マラリアに目をむける機会を与えてくださった日本大 学村田浩一博士, 佐藤雪太博士に深く感謝します. 最後 に, 共同研究者として野外調查に協力し, 吸血源動物の 同定や鳥マラリア原虫の検出など分子生物学的分析を忍 耐強く行ってくださった金京純博士に心から感謝いたし ます。

\section{引用文献}

Ahumada, J. A., LaPointe, D. and Samuel, M. D. 2004. Modeling the population dynamics of Culex quinquefasciatus (Diptera: Culicidae), along an elevational gradient in Hawaii. J. Med. Entomol., 41: 1157-1170.

Anderson, R. M. and May, R. M. 1992. Infectious diseases of humans: dynamics and control. 757 pp., Oxford University Press, Oxford.

Applegate, J. E., Beaudoin, R. L. and Seeley, Jr. D. C. 1971. The effect of spring relapse in English sparrows on infectivity of malaria to mosquitoes. J. Wildl. Dis., 7: 91-92.

Aruch, S., Atkinson, C. T., Safage, A. F. and LaPointe, D. A. 2007. Prevalence and distribution of pox-lie lesions, avian malaria, and mosquito vectors in Kipahulu valley, Haleakala national park, Hawaii, USA. J. Wildl. Dis., 43: 567-575.

Bailey, N. T. J. 1982. The biomathematics of malaria. 210 pp., Charles Griffin \& Company, London.

Bak, U. B., Park, J. C. and Lim, Y. J. 1984. An outbreak of malaria in penguins at the Farm-land zoo. Korean J. Parasit., 22: 267-272.

Beier, J. C. and Stoskopf, M. K. 1980. The epidemiology of avian malaria in black-footed penguins Spheniscus demersus. J. Zoo Anim. Med., 11: 99-105.

Bensch, S., Hellgren, O. and Pérez-Tris, J. 2009. MalAvi: a public database of malaria parasites and related haemosporidians in avian hosts based on mitochondrial cytochrome b lineages. Mol. Ecol. Resources, 9: 13531358.

Bensch, S., Stjernman, M., Hasselquist, D., Östman, Ö., Hansson, B., Westerdahl, H. and Pinheiro, R. T. 2000. Host specificity in avian blood parasites: a study of Plasmodium and Haemoproteus mitochondrial DNA amplified from birds. Proc. R. Soc. Lond. B, 267: 15831589.

Bensch, S., Waldenström, J., Jonzén, N., Westerdahl, H., Hansson, B., Sejberg, S. and Hasselquist, D. 2007. Temporal dynamics and diversity of avian malaria parasites in a single host species. J. Anim. Ecol., 76: 112-122.

Boakye, D. A., Tang, J., Trunc, P., Merriweather, A. and Unnasch, T. R. 1999. Identification of bloodmeals in haematophagous diptera by cytochrome B heteroduplex analysis. Med. Vet. Entomol., 13: 282-287.

Buescher, E. L., and Scherer, W. F. 1959. Ecologic studies of Japanese encephalitis virus in Japan: IX. epidemio- logic correlations and conclusions. Am. J. Trop. Med. Hyg., 8: 719-722.

Bullock, H. R., Murdoch, W. P., Fowler, H. W. and Brazzel, H. R. 1959. Note on the overwintering of Culex tritaeniorhynchus Giles in Japan. Mosq. News, 19: 184188.

Burkett-Cadena, N. D., Eubanks, M. D. and Unnasch, T.R. 2008. Preference of female mosquitoes from natural and artificial resting sites. J. Am. Mosq. Control Assoc., 24: 228-235.

Ejiri, H., Sato, Y., Kim, K. S., Hara, T., Tsuda, Y., Imura, T., Murata, K. and Yukawa, M. 2011. Entomological study on transmission of the avian malaria parasite in a zoological garden in Japan: Blood-meal identification and detection of avian malaria parasite DNA from bloodfed mosquitoes. J. Med. Entomol., 48: 600-607.

Ejiri, H., Sato, Y., Sasaki, E., Sumiyama, D., Tsuda, Y., Sawabe, K., Matsui, S., Horie, S., Akatani, K., Takagi, M., Omori, S., Murata, K. and Yukawa, M. 2008. Detection of avian Plasmodium spp. DNA sequences from mosquitoes captured in Minami Daito Island of Japan. J. Vet. Med. Sci., 70: 1205-1210.

Ejiri, H., Sato, Y., Sawai, R., Sasaki, E., Matsumoto, R., Ueda, M., Higa, Y., Tsuda, Y., Omori, S., Murata, K. and Yukawa, M. 2009. Prevalence of avian malaria parasite in mosquitoes collected at a zoological garden in Japan. Parasitol. Res., 105: 629-633.

Fallon, S. M., Bermingham, E. and Ricklefs, R. E. 2005. Host specialization and geographic localization of avian malaria parasites: a regional analysis in the Lesser Antilles. Am. Nat., 165: 466-480.

Fix, A. S., Waterhouse, C., Greiner, E. C. and Stoskopf, M. K. 1988. Plasmodium relictum as cause of avian malaria in wild-caught magellanic penguins (Speniscus magellanicus). J. Wildl. Dis., 24: 610-619.

Fukumi, H., Hayashi, K., Mifune, K., Shichijo, A., Matsuo, S., Omori, N., Wada, Y., Oda, T., Mogi, M. and Mori, A. 1975. Ecology of Japanese encephalitis virus in Japan. I. Mosquito and pig infection with the virus in relation to human incidence. Trop. Med., 17: 97-110.

Gabaldon, A. and Ulloa, G. 1980. Holoendemicity of malaria: an avian model. Trans. R. Trop. Med. Hyg., 74: 501-507.

Gogolin, L. R. and Freier, J.E. 1986. Avian malaria among house sparrows: a survey of disease and mosquito vectors (Diptera: Culicidae) in Reed City, Michigan. The Great Lake Entomol., 19: 43-50.

Hamer, G. L., Kitron, U. D., Brawn, J. D., Loss, S. R., Ruiz, M. O., Goldberg, T. L. and Walker, E. D. 2008. Culex pipiens (Diptera: Culicidae): a bridge vector of West Nile virus to humans. J. Med. Entomol., 45: 125-128.

Hamer, G. L., Kitron, U. D., Goldberg, T. L., Brawn, J. D., Loss, S. R., Ruiz, M. O., Hayes, D. B. and Walker, E. D. 2009. Host selection by Culex pipiens mosquitoes and West Nile virus amplification. Am. J. Trop. Med. Hyg., 80: 268-278.

原田文雄, 小林一郎, 森谷清樹, 原田久雄, 石井襄二. 
1962. 日本脳炎の疫学に関する野外実験 (2) 神奈川県下 の越冬蚊採集成績. 神奈川県衛研年報, 12: 66-79.

Hayashi, K., Mifune, K., Shichijo, A., Suzuki, H., Matsuo, S., Makino, Y., Akashi, M., Wada, Y., Oda, T., Mogi, M. and Mori, A. 1975. Ecology of Japanese encephalitis virus in Japan. III. The results of investigation in Amami island, southern part of Japan, from 1973 to 1975. Trop. Med., 17: 129-142.

Higa, Y., Hoshino, K., Tsuda, Y. and Kobayashi, M. 2006. Dry ice-trap and human bait collection of mosquitoes in the eastern part of Hokkaido, Japan. Med. Entomol. Zool., 57: 93-98.

Huijben, S., Schaftenaar, W., Wijsman, A., Paaijmans, K. and Takken, W. 2007. Avian malaria in Europe: an emerging infectious disease? In: Emerging pests and vector-borne diseases in Europe. (ed. Takken, W. and Knols, B.G.J.), pp. 59-74, Wageningen Academic Publishers, Wageningen.

平田晶子, 上条隆志, 中村 徹. 2006. 関東地方東部に おける人工林の種組成とその地理的分布. 植生学会誌, 23: 119-136.

Irby, W. S. and Apperson, C. S. 1992. Spatial and temporal distribution of resting female mosquitoes (Diptera: Culicidae) in the coastal plain of North Carolina. J. Med. Entomol., 29: 150-159.

Ishtiaq, F., Guillaumot, L., Clegg, S. M., Phillimore, A. B., Black, R. A., Owens, I. P. F., Mundy, N. I. and Sheldon, B. C. 2008. Avian haematozoan parasites and their association with mosquitoes across Southwest Pacific Islands. Mol. Ecol., 17: 4545-4555.

Ito, S., Buei, K., Yoshida, M. and Nakamura, H. 1986. Ecological studies on the overwintering of mosquitoes, especially Culex tritaeniorhynchus Giles in Osaka Prefecture. 2. Physiological age composition of overwintered females and population density of adults and larvae in autumn. Jpn. J. Sanit. Zool., 37: 341-347.

加納六郎. 1950. 鳥マラリアの研究 (2) 日本産野鳥の鳥マラ リアの感受性. 日本細菌学雑誌, 5: 77-80.

Kawai, S. 1969. Studies on the follicular development and feeding activity of the females of Culex tritaeniorhynchus with special reference to those in autumn. Trop. Med., 11: 145-169.

Kent, R., Juliusson, L., Weissmann, M., Evans, S. and Komar, N. 2009. Seasonal blood-feeding behavior of Culex tarsalis (Diptera: Culicidae) in Weld County, Colorado, 2007. J. Med. Entomol., 46: 380-390.

Kent, R. J. and Norris, D. E. 2005. Identification of mammalian blood meals in mosquitoes by a multiplexed polymerase chain recaction targeting cytochrome $\mathrm{B}$. Am. J. Trop. Med. Hyg., 73: 336-342.

Kent, R. J., Thuma, P. E., Mharakurwa, S. and Norris, D. 2007. Seasonality, blood feeding behavior, and transmission of Plasmodium falciparum by Anopheles arabiensis after an extended drought in southern Zambia. Am. J. Trop. Med. Hyg., 76: 267-274.

Kilpatrick, A. M., Daszak, P., Jones, M. J., Marra, P. P. and Kramer, L. D. 2006a. Host heterogeneity dominates
West Nile virus transmission. Proc. R. Soc. Lond. B, 273: 2327-2333.

Kilpatrick, A. M., Kramer, L. D., Campbell, S. R., Alleyne, E. O., Dobson, A. P. and Daszak, P. 2005. West Nile virus risk assessment and the bridge vector paradigm. Emerg. Infect. Dis., 11: 425-429.

Kilpatrick, A. M., Kramer, L. D., Jones, M. J., Marra, P. P. and Daszak, P. 2006b. West Nile virus epidemics in North America are driven by shifts in mosquito feeding behavior. Plos Biol., 4: 1-5.

Kim, H. C., Lee, K. W., Klein, T. A. and Strickman, D. A. 1999. Seasonal prevalence of mosquitoes collected from light trap in Korea (1995-1996). Korean J. Entomol., 29: 181-187.

Kim, K. S., Tsuda, Y., Sasaki, T., Kobayashi, M. and Hirota, Y. 2009a. Mosquito blood meal analysis for avian malaria study in wild bird communities: laboratory verification and application to Culex sasai (Diptera: Culicidae) collected in Tokyo, Japan. Parasitol. Res., 105: 1351-1357.

Kim, K. S., Tsuda, Y. and Yamada, A. 2009b. Blood-meal identification and detection of avian malaria parasite from mosquitoes (Diptera: Culicidae) inhabiting coastal areas of Tokyo Bay, Japan. J. Med. Entomol., 46: 1230-1234

Kim, K. S. and Tsuda, Y. 2010. Seasonal changes in feeding pattern of Culex pipiens pallens govern transmission dynamics of multiple lineages of avian malaria parasite in Japanese wild bird community. Mol. Ecol., 19: 5545-5554.

Kliewer, J. W., Miura, T. and Chapman, H. C. 1969. Seasonal occurrence and physiology of Culex tarsalis in the foothills of Fresno County, California. Ann. Entomol. Soc. Am., 62: 13-18.

Krafsur, E. S. 1977. The biology and relative prevalence of Anopheles species with respect to the transmission of Plasmodium to man in western Ethiopia. J. Med. Entomol., 14: 180-194.

Lee, J. H., Hassan, H., Hill, G., Cupp, E. W., Higazi, T., Mitchell, C. J., Godsey, Jr., M. S. and Unnasch, T. R. 2002. Identification of mosquito avian-derived blood meals by polymerase chain reaction-heteroduplex analysis. Am. J. Trop. Med. Hyg., 66: 599-604.

Macdonald, G. 1957. The epidemiology and control of malaria. pp. 201., Oxford University Press, London.

Maekawa, Y., Tsuda, Y., Dachlan, Y. P., Yotopranoto, S., Gerudug, I. K. K., Yoshinaga, K., Kanbara, H. and Takagi, M. 2009. Anopheline fauna and incriminatory malaria vectors in malaria endemic areas on Lombok Island, Indonesia. Med. Entomol. Zool., 60: 1-11.

Massey, B., Glesson, D. M., Slaney, D. and Tompkins, D. M. 2007. PCR detection of Plasmodium and blood meal identification in a native New Zealand mosquito. J. Vect. Ecol., 32: 154-156.

松本令以, 植田美弥, 佐藤雪太, 比嘉由紀子, 津田良 夫，澤辺京子，村田浩一. 2006. よこはま動物園におけ る鳥マラリアの発生と対策. 獣医畜産新報, 59: 827-830. 
Matsuzaki, S. 1990. Population dynamics of Culex tritaeniorhynchus in relation to the epidemics of Japanese encephalitis in Kochi Prefecture, Japan. Jpn. J. Sanit. Zool., 41: 247-255.

Ming, J. G. and Xue, M. 1996. Progress in studies on the overwintering of the mosquito Culex tritaeniorhynchus. Southeast Asian J. Trop. Med. Publ. Hlth., 27: 810-817.

Ming, J. G., Jin, H., Riley, J. R., Reynolds, D. R., Smith, A. D., Wang, R. L., Cheng, J. Y. and Cheng, X. N. 1993. Autumn southward return migration of the mosquito Culex tritaeniorhynchus in China. Med. Vet. Entomol., 7: 323-327.

Mitchell, C. J. 1988. Occurrence, biology, and physiology of diapause in overwintering mosquitoes, pp. 191-218. In: T. P. Monath (ed.), The arboviruses: epidemiology and ecology, vol. 1. CRC, Boca Raton, FL.

Mogi, M. 1978. Population studies on mosquitoes in the rice field area of Nagasaki, Japan especially on Culex tritaeniorhynchus. Trop. Med., 20: 173-263.

Mogi, M., Kawai, S., Oda, T., Nishigaki, J., Suenaga, O., Ito, S., Miyagi, I., Wada, Y. and Omori, N. 1970. Ecology of vector mosquitoes of Japanese encephalitis, especially of Culex tritaeniorhynchus 3. Seasonal changes in the time of being attracted to dry ice in the females of Culex tritaeniorhynchus. Trop. Med., 12: 122-127.

Molaei, G., Andreadis, T. G., Armstrong, P. M., Anderson, J. F. and Vossbrinck, C. R. 2006. Host feeding patterns of Culex mosquitoes and West Nile virus transmission, Northeastern United States. Emerg. Inf. Dis., 12: $468-474$.

Morris, C. D. 1981. A structural and operational analysis of diurnal resting shelters for mosquitoes (Diptera: $\mathrm{Cu}$ licidae). J. Med. Entomol., 18: 419-424.

Mukabana, W. R., Takken, W., Seda, P., Killeen, G. F., Hawley, W. A. and Knols, B. G. 2002. Extent of digestion affects the success of amplifying human DNA from blood meals of Anopheles gambiae (Diptera: $\mathrm{Cu}-$ licidae). Bull. Entomol. Res., 92: 233-239.

Murata, K. 2002. Prevalence of blood parasites in Japanese wild birds. J. Vet. Med. Sci., 64: 785-790.

Murata, K., Nii, R., Sasaki, E., Ishikawa, S., Sato, Y., Sawabe, K., Tsuda, Y., Matsumoto, R., Suda, A. and Ueda, M. 2008. Plasmodium (Bennettinia) juxtanucleare infection in a captive white eared-phesant (Crossoptilon crossoptilon) at a Japanese zoo. J. Vet. Med. Sci., 70: 203-205.

Mwandawiro, C., Tuno, N., Suwonkerd, W., Tsuda, Y., Yanagi, T. and Takagi, M. 1999. Host preference of Japanese encephalitis vectors in Chiangmai, Northern Thailand. Med. Entomol. Zool., 50: 323-333.

中尾舜一. 1959a. 草地の昼間潜伏蚊類群集の生態学的 研究. 第 1 報, 群集構造の動態. 衛生動物, 10: 1-7.

中尾舜一. 1959b. 草地の昼間潜伏蚊類群集の生態学的 研究. 第3 報, 数種の蚊の潜伏習性. 衛生動物, 10 : $8-15$.

Njabo, K. Y., Cornel, A. J., Sehgal, R. N. M., Loiseau, C., Buermann, W., Harrigan, R. J., Pollinger, J., Valkiunas,
G. and Smith, T. B. 2009. Coquillettidia (Culicidae, Diptera) mosquitoes are natural vectors of avian malaria in Africa. Mal. J., 8: 193.

Nelson, M. J. 1971. Mosquito studies (Diptera: Culicidae) XXVI. Winter biology of Culex tarsalis in Imperial valley, California. Contr. Am. Entomol. Inst., 7: 1-56.

Oda, T. and Wada, Y. 1973. On the gonotrophic dissociation in Culex tritaeniorhynchus summorosus females under various conditions. Trop. Med., 15: 189-195.

Oda, T., Wada, Y. and Mori, A. 1978. Follicular degeneration in unfed nulliparous females of Culex tritaeniorhynchus. Trop. Med., 20: 153-155.

緒方一喜, 田中生男, 水谷 澄, 鈴木 猛, 大畑吉春, 西沢 伝, 小林英夫. 1968. コガタアカイエカ成虫の係 留場所に関する観察成績. 衛生動物, 19: 38-43.

Omori, N., Ito, S., Takenokuma, M., Mifune, K., Shichijo, A. and Hayashi, K. 1965a. Experimental hibernation of Culex tritaeniorhynchus in Nagasaki, Japan. Endem. Dis. Bull. Nagasaki Univ., 7: 288-295.

Omori, N., Wada, Y., Kawai, S., Ito, S., Oda, T., Suenaga, O. and Nishigaki, J. 1965b. Preliminary notes on the collection of hibernated females of Culex tritaeniorhynchus in Nagasaki. Endem. Dis. Bull. Nagasaki Univ., 7: 147-153.

大沢雅彦. 1993. 東アジアの植生と気候. 科学 63: 664672.

Perkins, S. L. 2000. Species concepts and malaria parasites: detecting a cryptic species of Plasmodium. Proc. $R$. Soc. Lond. B, 267: 2345-2350.

Rao, R. T. 1984. The anophelines of India. pp. 518, Malaria Research Center, New Delhi.

Reeves, W. C., Herold, R. C., Rosen, L., Brookman, B. and Hammon, W. McD. 1954. Studies on avian malaria in vectors and hosts of encephalitis in Kern County, California. II. Infections in mosquito vectors, Am. J. Trop. Med. Hyg., 3: 696-703.

Reisen, W. K., Aslamkahn, M. and Basio, R. G. 1976. The effects of climatic patterns and agricultural practices on the population dynamics of Culex tritaeniorhynchus in Asia. Southeast Asian J. Trop. Med. Publ. Hlth., 7: 61-71.

Reiter, M. E. and LaPointe, D. A. 2007. Landscape factors influencing the spatial distribution and abundance of mosquito vector Culex quinquefasciatus (Diptera: $\mathrm{Cu}$ licidae) in a mixed residential-agricultural community in Hawaii. J. Med. Entomol., 44: 861-868.

Ricklefs, R. E., Swanson, B. L., Fallon, S. M., MartinezAbraom, A., Scheuerlein, A., Gray, J. and Latta, S. C. 2005. Community relationships of avian malaria parasites in southern Missouri. Ecol. Monogr., 75: 543-559.

Rosen, L. and Reeves, W. C. 1954. Studies on avian malaria in vectors and hosts of encephalitis in Kern County, California. III. The comparative vector ability of some of the local culicine mosquitoes. Am. J. Trop. Med. Hyg., 3: 704-708.

Saitoh, Y., Hattori, J., Chinone, S., Nihei, N., Tsuda, Y., Kurahashi, H. and Kobayashi, M. 2004. Yeast-gener- 
ated $\mathrm{CO}_{2}$ as a convenient source of carbon dioxide for adult mosquito sampling. J. Am. Mosq. Control Assoc., 20: $261-264$.

酒井 昭. 1975. 日本における常緑及び落葉広葉樹の 耐凍度とそれらの分布との関係. 日本生態学会誌, 25: 101-111.

Sawabe, K., Isawa, H., Hoshino, K., Sasaki, T., Roychoudhury, S., Higa, Y., Kasai, S., Tsuda, Y., Nishiumi, I., Hisai, N., Hamao, S. and Kobayashi, M. 2010. Hostfeeding habits of Culex pipiens and Aedes albopictus (Diptera: Culicidae) collected at the urban and suburban residential areas of Japan. J. Med. Entomol., 47: 442-450.

Scherer, W. F., Buescher, E. L., Flemings, M. B., Noguchi, A. and Scanlon, J. 1959. Ecologic studies of Japanese encephalitis virus in Japan: III. mosquito factors. zootropism and vertical sight of Culex tritaeniorhynchus with observations on variations in collections from animal-baited traps in different habitats. Am. J. Trop. Med. Hyg., 8: 665-677.

Service, M. W. 1971. The daytime distribution of mosquitoes resting in vegetation. J. Med. Entomol., 8: 271-278. 城谷歩惟, 柴田明弘, 江尻寛子, 佐藤雪太, 畠山吉則, 岩野英俊, 津田良夫, 村田浩一, 湯川眞嘉. 2009. 神 奈川県内の大学農場における蚊の分布および鳥マラリア 原虫保有状況. 日本獣医師会雑誌, 62: 73-79.

Silver, J. B. 2008. Mosquito ecology, field sampling methods $3^{\text {rd }}$ ed., 1494 pp., Springer, New York.

Takagi, M., Sugiyama, A. and Maruyama, K. 1995. Effect of rice culturing practices on seasonal occurrence of Culex tritaeniorhynchus (Diptera: Culicidae) immature in three different types of rice-growing areas in central Japan. J. Med. Entomol., 32: 112-118.

Trung, H. D., Bortel, W. V., Sochantha, T., Keokenchanh, K., Quang, N. T., Cong, L. D. and Coosemans, M. 2004. Malaria transmission and major malaria vectors in different geographical areas of Southeast Asia. Trop. Med. Inter. Health, 9: 230-237.

津田良夫, 比嘉由紀子, 伊澤晴彦, 星野啓太, 澤辺京 子, 小林睦生. 2005. ウエストナイルウイルスの主要媒介 蚊を決定する生態的特徴. 臨床とウイルス, 33: 17-21.

津田良夫, 比嘉由紀子, 倉橋 弘, 林 利彦, 星野啓 太, 駒形 修, 伊澤晴彦, 葛西真治, 佐々木年則, 冨 田隆史, 澤邊京子, 二瓶直子, 小林睦生. 2006a. 都 市域における疾病媒介蚊の発生状況調査一ドライアイス トラップを用いた 2 年間の調査結果一. 衛生動物, 57 : 75-82.

津田良夫, 比嘉由紀子, 暮西真治, 伊澤晴彦, 星野啓 太，林 利彦，駒形 修，澤邊京子，佐々木年則, 冨 田隆史, 二瓶直子, 倉橋 弘, 小林睦生. 2006b. 成 田国際空港近接地と周辺地域の媒介蚊調査（2003, 2004年) 衛生動物, 57: 211-218.

Tsuda, Y. and Kim, K. S. 2008. Sudden autumnal appearance of adult Culex tritaeniorhynchus Giles (Diptera: Culicidae) at a park in urban Tokyo-First field evidence for pre-diapause migration. J. Med. Entomol., 45: 610-616.
Tsuda, Y. and Kim, K. S. 2010. Prediapause migration and overwintering of Culex tritaeniorhynchus (Diptera: Culicidae) observed in a park in urban Tokyo during 2007 and 2009. Med. Entomol. Zool., 61: 69-78.

Tsuda, Y., Matsui, S., Saito, A., Akatani, K., Sato, Y., Takagi, M. and Murata, K. 2009a. Ecological study on avian malaria vectors on an oceanic island of Minami-Daito, Japan. J. Am. Mosq. Control Assoc., 25: 279-284.

Tsuda, Y., Sasaki, E., Sato, Y., Katano, R., Komagata, O., Isawa, H., Kasai, S. and Murata, K. 2009b. Results of mosquito collection from coastal areas of Tokyo Bay receiving migratory birds. Med. Entomol. Zool., 60: 119-124.

Valkiunas, G. 2005. Avian malaria parasites and other haemosporidia. 932 pp., CRC Press, New York.

van Riper III, C. 1991. The impact of introduced vectors and avian malaria on insular passeriform bird populations in Hawaii. Bull. Soc. Vector Ecol., 16: 59-83.

van Riper III, C., van Riper, S. G., Goff, M. L. and Laird, M. 1986. The epizootiology and ecological significance of malaria in Hawaiian land birds. Ecol. Monogr., 56: 327-344.

和田芳武. 1970. コガタアカイエカ類の生態の研究 III. 野外における休息習性の比較考察. 衛生動物, 21: 54-60.

和田芳武, 三浦悌二, 神谷正男, 豊川行平. 1968. 伊豆 半島および千葉県鋸山における越冬蚊採集成績. 衛生 動物, 19: 82-83.

Wada, Y., Kawai, S., Ito, S., Oda, T., Nishigaki, J., Omori, N., Hayashi, K., Mifune, K. and Shichijo, A. 1967. Ecology of vector mosquitoes of Japanese encephalitis, especially of $C x$. tritaeniorhynchus 1 . Results obtained in 1965. Trop. Med., 9: 45-57.

Wada, Y., Kawasi, S., Oda, T., Miyagi, I., Suenaga, O., Nishigaki, J., Omori, N., Takahashi, K., Matsuo, R., Itoh, T. and Takatsuki, Y. 1969. Dispersal experiment of Culex tritaeniorhynchus in Nagasaki area (Preliminary report). Trop. Med., 11: 37-44.

Wada, Y., Oda, T., Mogi, M., Suenaga, O., Miyagi, I., Omori, N., Ito, S. and Nishigaki, J. 1973. Ecology of vector mosquitoes of Japanese encephalitis, especially of Culex tritaeniorhynchus summorosus. 5. Overwintering of Culex tritaeniorhynchus summorosus and Anopheles sinensis. Trop. Med., 15: 11-22.

Wada, Y., Oda, T., Mogi, M., Mori, A., Omori, N., Fukumi, H., Hayashi, K., Mifune, K., Shichijo, A. and Matsuo, S. 1975. Ecology of Japanese encephalitis virus in Japan. II. The population of vector mosquitoes and the epidemic of Japanese encephalitis. Trop. Med., 17: 111-127.

Watanabe, M., Arakawa, R. and Kamimura, K. 1990. Relationship between yearly change of captured numbers and insecticide resistance of Culex tritaeniorhynchus in Toyama Prefecture. Jpn. J. Sanit. Zool., 41: 59-62.

吉岡邦二. 1954. 東北地方森林の群落学的研究（第 4 報）スダジイ北限地帯の森林. 植物生態学会報, 3: 219-229. 